\title{
POLLITIKK
}

\section{Amerikansk strategisk återhållsamhet och europeisk strategisk respons - tre typer av strategisk respons mot bakgrund av Brexit}

\author{
Ronnie Hjorth \\ Försvarshögskolan i Stockholm, Sverige \\ Malena Britz \\ Försvarshögskolan i Stockholm, Sverige
}

\begin{abstract}
Sammandrag
Den här artikeln identifierar och analyserar tre olika reaktioner, i artikeln benämnda "strategisk respons", på amerikansk strategisk återhållsamhet sedan 2017 och mot bakgrund av Brexit: "Liberal övervintring», "Ett starkare Europa» och »En bredare koalition». Analysen kopplar strategisk respons, strategiskt aktörskap och strategisk autonomi och leder till två slutsatser: För det första att Brexit snararare har gynnat än hindrat det europeiska säkerhets- och försvarssamarbetet, såväl inom ramen för EU som mellan EU och stater som står utanför EU, däribland Storbritannien. För det andra att den framväxande säkerhetsordningen innebär nya och annorlunda förutsättningar för det säkerhets- och försvarspolitiska samarbetet i Europa, inte minst i Norden.
\end{abstract}

Nøkkelord: transatlantisk säkerhet • europeisk säkerhet • nordisk säkerhet • brexit $\bullet$ internationell politik

\section{Inledning}

Sedan 2016 har flera initiativ tagits för att vidareutveckla och förstärka säkerhetsoch försvarspolitiska samarbeten i Europa. Särskilt tre utmaningar har varit kritiska: det försämrade säkerhetsläget främst till följd av Rysslands politik gentemot Ukraina

\footnotetext{
^Kontaktinformasjon: Ronnie Hjorth, e-post: ronnie.hjorth@fhs.se

(C2021 Ronnie Hjorth og Malena Britz. This is an Open Access article distributed under the terms of the Creative Commons Attribution 4.0 International License (http://creativecommons.org/licenses/by/4.0/), allowing third parties to copy and redistribute the material in any medium or format and to remix, transform, and build upon the material for any purpose, even commercially, provided the original work is properly cited and states its license. 
och annekteringen av Krim våren 2014, ökade krav från USA på de europeiska Natoländerna att bidra med målet 2 procent av BNP samt president Donald J. Trumps svävande besked om amerikanskt stöd till Europa. Till detta kommer den utdragna Brexitprocessen som aktualiserat Storbritanniens roll när det gäller säkerhets- och försvarspolitik i Europa.

Ambitionen att tydliggöra den samlade europeiska säkerhets- och försvarspolitiken och att stärka den europeiska förmågan är inte ny. Den kan både förklaras av ambitionen att vidareutveckla EU som en strategiskt autonom aktör - processer som både emanerar inifrån organisationen och dess medlemsstater - och som en reaktion på en föränderlig omvärld (Smith, 2018). Även det händelseförlopp som fick stämningsläget i Europa att präglas av närmast ett chocktillstånd våren 2017 hade sina orsaker såväl inom Europa och EU som i händelser utanför, något som tydligt avspeglades i det årets Münchenkonferens. Oron gällde Rysslands nya roll, president Trumps motstridiga budskap, fake news och post truth, demokratins framtid i USA och i världen i övrigt, migration, Brexit, EU:s framtid och den liberala världsordningen som betraktades som åtminstone tillfälligt överspelad. Den omedelbara orsaken, eller åtminstone utlösande faktorn, till detta stämningsläge var trots allt en förändrad och dessutom oklar amerikansk utrikespolitik. President Trump villkorade USA:s stöd till Europa och ifrågasatte därmed den transatlantiska länken. Trump frånsade sig den ledande rollen i världspolitiken och förordade istället "Amerika främst». Våren 2017 diskuterades till och med om USA nu skulle slå in på en isolationistisk linje (Munich Security Conference, 2017). Med tiden har den utrikespolitiska »linjen» stabiliserats något och kan kanske närmast karaktäriseras som en intressebaserad unilateralism.

Åsikterna om Trumps ledarskap och om den förändring som inträffat går isär, men i mycket representerar den amerikanska politiken ändå kontinuitet. En sådan aspekt är strategisk återhållsamhet (Strategic Restraint). Som vi återkommer till nedan har USA:s ambition att begränsa engagemanget i Europa funnits alltsedan det kalla krigets slut men den har artikulerats mer brutalt av Trump än av någon annan amerikansk president före honom. Till detta kommer naturligtvis en mer offensiv rysk hållning som gör den europeiska situationen mer prekär. Orsakerna bakom olika försvarsinitiativ i Europa är alltså flera. Vår utgångspunkt är dock att olika insatser i alla händelser är uttryck för vad vi kallar "strategisk respons» och som sådana ett svar på amerikansk "strategisk återhållsamhet». Utan att förringa de olika anledningar som ligger bakom en förändrad säkerhets- och försvarspolitik i flera europeiska stater och i samarbete mellan dem, vare sig dessa ansträngningar emanerar ur interna processer eller är att betrakta som reaktioner på en föränderlig omvärld, så är vår utgångspunkt att de formuleras i relation till och mot bakgrund av den amerikanska positionen. Den transatlantiska länken har under efterkrigstiden varit grundläggande för europeisk säkerhets- och försvarspolitik och europeisk strategisk respons, som vi uppfattar den, uttrycker i huvudsak en vilja att vidmakthålla eller utveckla den transatlantiska länken snarare än en ambition att montera ner eller ersätta den. 
Trots en gemensam strävan visar den här artikeln att den förändringsprocess som påbörjats även blottlägger motsättningar och konfliktlinjer.

Svaret på amerikansk strategisk återhållsamhet ser vi alltså som europeisk strategisk respons. Den här artikeln lyfter fram tre typer av strategisk respons i den aktuella situationen:

1. Liberal övervintring - som på olika sätt bygger på föreställningen att det nya osäkra är tillfälligt och att internationalism och multilateralism där USA har en ledande roll återkommer.

2. Ett starkare Europa - som i ett förändrat säkerhetsläge bygger på tanken att Europa inom ramen för EU bör bygga en starkare gemensam förmåga.

3. En bredare koalition - som beaktar Europa även utanför EU och dessutom i relation till andra stater på global nivå.

De tre är inte nödvändigtvis oförenliga utan opererar snarare i olika tidsdimensioner, från det kortsiktiga till det långsiktiga. Det går däremot inte att utifrån vår undersökning fastställa att de tre typer av respons är att betrakta som en sammanhållen strategi. De motsättningar och åsiktsbrytningar som föreligger talar snarast mot en sådan tolkning. Dessutom kan det förstås finnas andra exempel på strategisk respons från enskilda stater eller grupper av stater, exempelvis stater som av olika anledningar ser bilaterala säkerhetsgarantier från USA som det centrala, men det behöver i princip inte stå i motsättning till de strategier vi skisserar.

Den här artikeln baseras på både primärmaterial, som till exempel officiella dokument, och på sekundärmaterial, främst i form av rapporter och vetenskapliga publikationer. De tre typerna av strategisk respons baseras alltså på empiriska reflektioner. Syftet med artikeln att karaktärisera de tre formerna för strategisk respons och dessutom säga något om hur dessa sammantaget visar på konturerna av en föränderlig säkerhets- och försvarspolitisk ordning i Europa där ett tydligare europeiskt strategiskt aktörskap kan skönjas liksom en strävan i riktning mot strategisk autonomi. I dagsläget är det förstås inte möjligt att dra några säkra slutsatser om hur det hela kommer att utvecklas på längre sikt eftersom så många olika parametrar kommer att vara avgörande. Texten är därför snarast explorativ, men tre aspekter vill vi särskilt lyfta fram:

För det första vill vi betona det element av kontinuitet som trots allt finns i den amerikanska politiken och som vi identifierar som strategisk återhållsamhet. Det är därför sannolikt ett inslag även med Joe Biden som president och trots ett återvändande till mer av multilaterala lösningar. För det andra kan vi konstatera att Brexit, tvärtemot vad man skulle kunna förvänta sig, snarast har gynnat det framväxande nya säkerhets- och försvarssamarbetet. I sin strävan att återta kontroll har den brittiska regeringen ställt sig utanför EU-samarbetet även på det säkerhets- och försvarspolitiska området, men viljan att ändå spela en roll har lett till att britterna har kommit att acceptera ett mer långtgående samarbete med EU än vad man rimligen hade gått med på om utgången av folkomröstningen 2016 blivit den motsatta. 
För det tredje skapar den framväxande säkerhetsordningen nya förutsättningar för samarbete i Europa, inte minst i Norden. Främst är det utvecklingen av försvarssamarbetet PESCO inom EU samt European Intervention Initiative (EI2) som innebär att den tidigare strikta funktionsuppdelningen mellan Nato och EU lättas upp och att därmed förutsättningarna för nordiskt samarbete förändras.

Inledningsvis presenteras den amerikanska politiken utifrån begreppet strategisk återhållsamhet. Därefter utvecklas begreppen strategisk respons, strategiskt aktörskap och strategisk autonomi. I de följande tre avsnitten karaktäriseras de tre typerna av strategisk respons på ett sätt som belyser förutsättningarna för strategiskt aktörskap och strategisk autonomi. Två avgränsningar ska nämnas:Vi väljer att i den här artikeln inte mer än i förbigående behandla den tämligen snåriga mängd bilaterala avtal och förpliktelser som har etablerats. Inte heller har vi valt att behandla de interna processer som pågår inom Nato. Kortare citat på engelska har översatts av författarna.

\section{Amerikansk strategisk återhållsamhet}

Både ryskt och amerikanskt agerande har de senaste åren utmanat den världsordning som Europa existerat i sedan det kalla krigets slut. Ryssland har flyttat fram sina positioner på ett högst påtagligt sätt. Annekteringen av Krim våren 2014 och det ryska agerandet i Ukraina överhuvudtaget visade att Ryssland är berett att ta till militära medel också i Europa. Vidare har den ryska positionen stärkts genom skicklig diplomatisk och militär aktivitet i Syrien. Den oro som detta ledde till i Europa förstärktes av att president Trump redan från början satte press på Natos europeiska medlemsstater och framhöll att de har kapacitet att själva stå för en större del av sina kostnader för säkerhet och försvar. Ståndpunkten är knappast orimlig och delas av amerikanska forskare som inte i övrigt uppskattar den nuvarande amerikanska politiken men som förordar amerikansk strategisk återhållsamhet (se Walt, 2019). Bakgrunden till den amerikanska strategiska återhållsamheten i förhållande till Europa kan emellertid inte reduceras till Trump. Tvärtom fullföljde Trumpadministrationen i detta avseende en politik som pågått en längre tid, men han artikulerade den mer brutalt. En omprioritering av USA:s engagemang i Europa gjordes redan efter Sovjetunionens fall när inget militärt hot mot Europa längre förelåg. Under George W. Bush kom USA att fokusera i större utsträckning på inhemskt försvar och på kampen mot internationell terrorism. Till detta kommer diskussionen om s.k. "imperial overstretch» som länge pågått i USA, d.v.s. risken för att USA tar på sig ett alltför stort ansvar. Ett motmedel är just strategisk återhållsamhet som kan ta sig olika former, alltifrån multilaterala institutioner till unilateralt handlande (Gholtz et al., 1997; Ikenberry, 2001; Rosen, 2014). En aktuell litteratur som i flera avseenden påminner om Trumpadministrationens politik förespråkar så kallad »offshore balancing» innebärande att USA istället för att agera självt påverkar andra makter att ta ansvar för att balansera regionala stormakter, och att USA endast bör ingripa när det är nödvändigt (Layne, 1997; Mearsheimer \& Walt, 2016). 
Mycket talar därför för ett fortsatt minskat amerikanskt engagemang i Europa även efter Trump. Men han formulerade i två andra avseenden en politik i tydlig kontrast mot sina båda företrädare. För det första avvisade han den multilateralism som präglade Barack Obamas tid vid makten. För det andra avvisade han synen på USA som en garant för en liberal världsordning och som en förebild för världen $i$ övrigt. George W. Bush drev även han unilateralism, men med tydlig liberal profil där USA inte bara skulle föregå som liberalt exempel (exemplary politics) utan även aktivt skulle driva en liberal linje (vindicationist politics) (Monen, 2005). Den exceptionalism som betonades av Bush och som var ett uttryck för USA:s överlägsenhet har avvisats av Trump. Enligt en amerikansk forskare innebär detta att Trump i praktiken bidrar till att nedvärdera USA:s betydelse och status: USA framställs inte längre av presidenten som föredömligt - som "a city upon a hill» - utan som en stat bland andra, till och med som ett offer för andra makter och en stat i ständig konflikt med andra (Wertheim, 2018). Dessutom lyfte Trump för första gången sedan det kalla kriget fram stormaktskonkurrens som ett centralt inslag i den nationella säkerhetsstrategin (NSS, 2017, s. 28). Detta gjorde han trots att flera bedömare är eniga om att USA helt saknar konkurrens på den globala nivån och därför kommer att vara ohotad som supermakt i flera decennier (se t.ex. Beckley, 2018). Samtidigt som Trump framställde sig själv som den skicklige förhandlaren vars politik ska Make America Great Again förmedlade han inte bilden av USA som en global supermakt utan som en makt bland andra, utsatt för konkurrens. De amerikanska ställningstagandena sände hursomhelst signalen till europeiska stater att själva i större utsträckning ta ansvar för sin säkerhet och i en tid då säkerhetsläget försämrats.

\section{Strategisk respons}

Frågan om Europas och särskilt EU:s förmåga att agera strategiskt på ett samlat sätt är inte ny och har länge varit föremål för forskares kritiska blickar. Forskare som har studerat europeisk säkerhets- och försvarspolitik har betonat EU:s hittillsvarande oförmåga att formulera säkerhetsstrategier, att utöva strategi (Economides \& Sperling, 2018; Cottey, 2018) eller att vara en strategisk aktör (Engelbrekt, 2008). Det finns även en relativt livlig debatt om huruvida en europeisk strategisk kultur alls har utvecklats eller om EU överhuvudtaget kan eller bör ha en gemensam strategisk kultur, främst beroende på betydande skillnader mellan europeiska länders strategiska kulturer (Schmidt \& Zyla, 2013; Britz, 2016); Cottey hävdar till exempel att EU har utvecklat både institutioner och policy, exempelvis säkerhetsstrategin från 2004 och globala strategin från 2016, som namnen till trots inte är uttryck för egentlig samlande strategi. Grundläggande element i en strategi saknas, bland annat konsensus beträffande användning av militära maktmedel (Britz, 2016, s. 9). Vidare är rollfördelningen mellan EU och Nato inte tydlig och frågan om balansen mellan integration och suveränitet inom säkerhets- och försvarspolitiken är olöst. Sammantaget innebär detta att EU enligt Cottey har begränsad strategisk autonomi i bemärkelsen förmåga att planera och genomföra militära operationer. 
Begreppet strategisk autonomi förekommer även i den politiska sfären och i olika policydokument, som till exempel den globala strategin eller i uttalanden av bland andra president Emmanuel Macron som har framställt just strategisk autonomi som ett mål för europeisk militär förmågeutveckling. Mot bakgrund av allt tydligare artikulerad strategisk återhållsamhet från USA:s sida har strategisk autonomi förvandlats från en vision till en högaktuell och brännande politisk fråga. Knutet till diskussionen om strategisk autonomi är begreppet strategiskt aktörskap som allmänt ses som en förutsättning för att strategisk autonomi ska vara möjlig. Inom aktörskapet ryms såväl strategiskt tänkande i form av beslutsfattande och underrättelser som strategiskt agerande, till exempel förmåga till mobilisering och nyttjande av militära resurser (Engelbrekt, 2008, s. 13).

De tre typerna av strategisk respons som vi diskuterar nedan ställer i varierande grad krav på Europa att agera självständigt och att etablera gemensam förmåga, inom eller utom formella organisationer, att utöva strategiskt aktörskap och att etablera en strategisk kultur. I vad som nu följer görs ett försök att skissera tre olika möjliga utvecklingslinjer utifrån vilka europeisk strategisk respons kan beskrivas och där förutsättningarna för strategiskt aktörskap och strategisk autonomi är centralt. De tre olika typerna av strategisk respons har vi kallat "liberal övervintring», "ett starkare Europa» och "en bredare koalition».

\section{Liberal övervintring}

En första strategi för att möta den oro och oförutsägbarhet som präglade 2017 var att visa fortsatt tilltro till den liberala ordningen och att betrakta det inträffade som något av en parantes. Grundtanken kan sammanfattas ungefär så att den liberala ordningen har så många förtjänster, bärs upp av så många institutioner, företag, samhälleliga aktörer och regeringar att den är mer legitim än något annat alternativ och dessutom bäst tjänar olika aktörers intressen, vilket även gör den stabil (se t.ex. Jervis et al., 2018). Problemet var hur den liberala ordningen skulle kunna försvaras när den angrips inte bara från Peking och Moskva utan även från Washington. Det är väl känt att USA under efterkrigstiden både uppfattats och uppfattat sig som en garant för en liberal världsordning om så krävs med militära medel. Självbilden har i mycket varit den som bland andra Henry Kissinger tecknat som en blandning av liberalism och realism (Kissinger, 1994).

Under senare tid har forskare och experter inte minst i USA engagerat sig i diskussionen om vad som kan komma att hända efter Trump (se Drezner, 2019; Rapp-Hooper \& Friedman Lissner, 2019). En ganska vanlig ståndpunkt är att det inte kommer att bli som tidigare och att det inte heller bör bli det. Som redan nämnts har USA sedan tidigare omprioriterat sin politik gentemot Europa. Även om den liberala världsordningen under hela efterkrigstiden och särskilt efter det kalla krigets slut drivits på och garanterats av USA:s dominerande ställning möjliggör USA:s överlägsenhet, inte minst militärt, att man kan kombinera strategisk återhållsamhet 
med sporadisk närvaro närhelst det tjänar amerikanska intressen, exempelvis genom att praktisera offshore balancing. Så länge ingen makt kan axla USA:s roll återstår kanske bara två alternativ: att den liberala världsordningen ytterligare eroderar när USA drar sig tillbaka eller att USA återigen stödjer liberala institutioner och bekämpar en antiliberal utveckling världen över. Om detta stämmer innebär liberal övervintring i praktiken en väntan på en omsvängning i amerikansk politik.

Tanken om liberal övervintring är emellertid bekväm både politiskt och retoriskt eftersom det liberala narrativet tycks vara det enda som på kort sikt kan hantera chocken från 2017. Liberalismen har varit den politiska huvudlinjen sedan andra världskriget i praktiskt taget hela västra Europa. Antiliberala högernationella krafter ifrågasätter idag liberalismen och EU-projektet. Att hävda den liberala ordningens fördelar förblir ofrånkomligen ett nödvändigt försvar även för EU. En första utmaning kom för EU i och med att Storbritannien aktiverade Artikel 50 och därmed inledde Brexit.

Under 2018 formulerades två dokument vägledande för Storbritanniens och EU:s positioner på det säkerhets- och försvarspolitiska området. Dels EU:s Political Declaration, som antogs av Europeiska rådet den 25 november, och dels det brittiska s.k. Chequers Agreement, som antogs den 12 juli. Som vi idag vet antog aldrig EU27 det brittiska dokumentet, och EU:s politiska deklaration accepterades inte heller av det brittiska parlamentet, men dokumenten visar på de likheter och skiljelinjer som präglat motsättningen mellan EU och Storbritannien. På flera punkter var parterna emellertid eniga, framför allt gällde det uppfattningen om gemensamma hot mot säkerheten liksom en övertygelse att samarbete mellan Storbritannien och EU bäst skyddar centrala intressen och värden. Så visar både Storbritannien och EU att skyddet av liberala värden fortsatt är centralt.

En annan punkt gällde Nato. Brexit innebär inte någon avgörande förändring vad gäller Storbritanniens förhållande till Nato under det att det för EU:s del innebär ett minskat inflytande i Nato. Efter Brexit skulle huvuddelen, år 2017 enligt uppgift cirka 80 procent, av Natos verksamhet och budget finansieras av stater utanför EU (Black et al., 2017, s. 78). Om den europeiska förmågan stärks blir EU en allt viktigare samarbetspartner till Nato och de ingående staterna stärker därför rimligen sin ställning inom Nato. För EU:s del har det även handlat om att hålla ihop unionen i relationen till Storbritannien på handelsområdet. Detta får inga större konsekvenser för försvars- och säkerhetspolitiken på grund av Nato och beroende på att kapacitetsfrågan huvudsakligen är nationell. Strategiskt aktörskap i den militära bemärkelse som diskuteras ovan krävs egentligen inte enligt det här synsättet, däremot krävs av unionen på kort sikt samlat agerande inom handelspolitiken. Den transatlantiska länken blir därför fortsatt en prioritet.

\section{Ett starkare Europa}

Ett annat sätt att reagera på amerikansk strategisk återhållsamhet sedan 2017 har varit att stärka Europas militära förmåga inom ramen för EU. Uppbyggnaden av europeiska 
institutioner på det säkerhets- och försvarspolitiska området är en väsentlig del av europeisk strategisk respons, även om denna process inte torde ge substantiella resultat på kort sikt. En respons av den här typen väcker frågan om strategisk autonomi i Europa, och det är en fråga som har kommit att bli politiskt kontroversiell.

Såväl Tysklands förbundskansler Angela Merkel som Frankrikes president Macron har tagit initiativ till att forma en ny europeisk säkerhetsordning. »Tiden är förbi,» sade Merkel, "då vi kunde fullt ut kunde lita på andra» och därför "måste vi nu kämpa för vår egen framtid, för vårt öde som européer» (Smale \& Erlanger, 2017). Macron uttryckte för sin del en önskan om »ett Europa som är bättre på att försvara sig självt ensamt och utan att enbart förlita sig på USA, ett mer suveränt Europa» (Munich Security Conference, 2019, s. 20). Föreställningen är dock att uppbyggandet av försvarsförmåga inom EU inte med nödvändighet står i motsatsställning till fortsatt samarbete inom ramen för Nato eller ersätter den transatlantiska länken. I linje med detta uttalade Tysklands tidigare försvarsminister och numera ordförande för EU-kommissionen Ursula von den Leyen att "vi vill fortsatt vara transatlantiska men samtidigt bli mer europeiska» (Munich Security Conference, 2019, s. 19).

Det står klart att uppbyggandet av militär förmåga i Europa under mycket lång tid inte kan mäta sig med den amerikanska kapaciteten. Däremot kan det innebära att USA kan minska sin närvaro och sina resurser i Europa och i dess närområden. Ska detta kunna ske på ett säkert sätt krävs att amerikanska säkerhetsgarantier inom Nato består. Dock finns naturligtvis en motsättning mellan att bygga egen förmåga och att lita till USA, en motsättning som även kan utnyttjas av amerikanska isolationister för att ytterligare dra tillbaka amerikanskt engagemang på den europeiska kontinenten. I en konfliktsituation möjliggör också detta arrangemang att USA kan låta Europa göra vad man kallar "the heavy lifting», d.v.s. överlämna åt europeiska stater att betala en större del av det militära priset (Walt, 2019, s. 27).

En tydlig satsning på den gemensamma säkerhets- och försvarspolitiken inleddes av EU under 2016 då unionen dels lanserade en implementeringsplan för den globala strategin, dels lanserade en Defence Action Plan där skapandet av European Defence Fund (EDF) var en viktig komponent. En betydelsefull utveckling inom EU gäller Permanent Structured Cooperation (PESCO) som tillkom i och med Lissabonfördraget men som inte realiserades förrän efter att Storbritannien folkomröstat för att lämna EU; detta parallellt med att EU i och med globala strategin indikerat en ambitionshöjning inom den gemensamma säkerhets- och försvarspolitiken. PESCO bildades 2017 med det primära syftet att stärka och effektivisera EU:s förmåga att hantera olika hot och för att stärka försvarssamarbetet inom EU. Ett viktigt syfte bakom PESCO är att åstadkomma strategisk autonomi för EU (PESCO, 2019, s. 1). PESCO är alltså avsett att stärka en för EU gemensam militär kapacitet och lägger på så sätt grunden för strategisk autonomi även i samarbete med andra aktörer. Den europeiska försvarsfonden (EDF) är ägnad att stärka och effektivisera den europeiska försvarsindustriella basen genom forsknings- och utvecklingsprojekt. Detta kan förväntas gynna förmågeuppbyggnad även om de rent ekonomiska 
drivkrafterna också är betydelsefulla. Slutligen har EU enats omkring Coordinated Annual Review (CARD) som en konsekvens av att EU redan 1999 började sätta mål för den europeiska förmågan, den s.k. "headline goal-processen", ett behov som ökar i och med utvecklingen av PESCO (Britz \& Eriksson, 2005, 2008). EU:s globala strategi slår fast ambitionen att ytterligare utveckla den samlade försvarsförmågan inom unionen. På den grunden tänker man sig ett samarbete med Nato men däremot inte att den europeiska förmågeuppbyggnaden ska koordineras av Nato. Uppfattningen är att när EU utvecklar EDF, PESCO och CARD kan man fullt ut bli en effektiv partner till bland annat Nato, men inte i motsättning till Nato (European Union, 2019).

Den brittiska hållningen till europeiskt säkerhets- och försvarssamarbete har efter folkomröstningen 2016 och i varje fall under Theresa Mays tid som premiärminister varit konsekvent. Redan 2017 uttryckte hon att "vi lämnar EU men vi lämnar inte Europa» och att samarbetet skulle fortsätta på det säkerhets- och försvarspolitiska området som hon beskrev som "ett nytt fördjupat och speciellt partnerskap» och en ordning "som sträcker sig bortom det existerande tredjelandsengagemanget» (Department of Exiting the European Union, 2017, s. 2). Detta skulle alltså kunna innebära särskilda fördelar för Storbritannien efter Brexit, exempelvis när det gäller samarbete inom ramen för EDF. Storbritannien skulle då inte vara tredje land utan "tredjeland +» eller "2 1/2». För att sätta kraft bakom orden betonas också den betydande brittiska militära kapaciteten och det faktum att Storbritannien vid tidpunkten deltog aktivt i samtliga operationer under den gemensamma säkerhets- och försvarspolitiken. Parterna är också i huvudsak eniga om att Storbritannien fortsatt deltar i sådana operationer som så kallad tredje part inom existerande ramar (Foreign Participation Agreement). Storbritannien accepterar att man efter Brexit inte kan ha en formell roll men förutskickar regelbunden kommunikation, konsultation och koordination. En liknande motsättning finns när det gäller hur säkerhets- och försvarssamarbetet inom EU ska struktureras. Storbritannien ser ett långtgående samarbete över ett brett säkerhetsområde inkluderande såväl utrikespolitik som försvar och samarbete på det rättspolitiska området (H. M. Government, 2018, s. 51).

Så långt är båda sidor i huvudsak eniga, men man är oenig om hur samarbetet ska struktureras. Även här eftersträvar Storbritannien ett mer omfattande samarbete. Det handlar bland annat om att fullt ut komma $\mathrm{i}$ åtnjutande av information och datasystem som exempelvis ECRIS och SIS II (H. M. Government, 2018, s. 6, 64). Forsknings- och utvecklingsarbete inom säkerhets- och försvarsområdet är ett annat område där britterna eftersträvar ett närmande till EU (H. M. Government, 2018, s. 67). EU har däremot inte varit berett att göra några undantag för Storbritannien som ett "tredjeland +» eftersom ett sådant undantag skulle äventyra distinktionen mellan en medlemsstat och ett tredje land. För EU har det varit viktigt att markera att Storbritannien efter Brexit hamnar utanför EU och inte nödvändigtvis har en fot kvar. Möjligen kan detta ändras med tiden när väl striderna om Brexit har lagt sig, men EU har hittills inte velat ge Storbritannien specialregler utan menar att 
Storbritanniens deltagande i planering och tillgång till dokumentation bör stå i proportion till insatsen och bestämmas från fall till fall (Council of European Union, 2018, s. 18). Vad gäller PESCO är bestämmelsen idag sådan att rådet måste enas om under vilka villkor andra stater "undantagsvis» kan inbjudas. Detta innebär att om Storbritannien ska vara med så måste det vara efter inbjudan. Liknande bestämmelser gäller inom exempelvis EDF (Regulation (EU) 2018/1092, 29).

En politiskt mer känslig motsättning mellan EU och Storbritannien gäller i vilken utsträckning EU bör tillskansa sig strategisk autonomi. Storbritannien lyfter fram Natos betydelse som »en hörnsten när det gäller europeiskt försvar och säkerhet» under det att EU snarast betraktas som ett "komplement». En ökning av försvarsutgifterna i riktning mot 2 procent av BNP menar man därför skulle användas mer effektivt inom ramen för Nato än i uppbyggnaden av en EU-styrka (Williamson, 2019). Detta står naturligtvis i strid mot EU:s ambition att tillförsäkra sig strategisk autonomi. Det hela kan nog förstås så att Nato uppfattas som en central organisation även från EU:s utgångspunkt men för att uttrycka det enkelt vill EU arbeta med Nato och inte för Nato.

Vad gäller strategisk autonomi är det från EU-håll och särskilt från franskt politiskt håll en tydlig önskan. Mycket av kapacitetsuppbyggnaden kan ses i ljuset av idén om strategisk autonomi åtminstone när det gäller insatser utomlands. Beträffande relationen mellan EU och Nato är det däremot inte givet hur balansen mellan suveränitet och integration inom säkerhets- och försvarspolitiken ska se ut, men det är möjligt att frågan blir något friare efter att Storbritannien har lämnat EU. Dessutom beror det på om frågan ses som en fråga om att genomföra insatser eller som en fråga om att bygga kapacitet i en vidare bemärkelse, inte minst försvarsindustriellt. Vad gäller strategisk kultur så kommer ökat samarbete med en vilja att öka möjligheterna till internationella insatser att tydliggöra skillnader i strategisk kultur där det är ganska stor skillnad på europeiska länder som vill delta i insatser och länder som inte vill. Tidigare forskning visar att detta i hög grad sammanfaller med geostrategisk position och historiska erfarenheter (Britz, 2016; Zandee \& Kruijver, 2019).

Faktum är trots allt att de förda förhandlingarna ändå har inneburit att Storbritannien accepterat en utveckling av institutioner som de antagligen inte hade gått med på om inte Brexit påbörjats. I och med omvärldsförändringarna och det "möjlighetsfönster» som öppnade sig för EU efter folkomröstningen i Storbritannien har man kunnat gå vidare och utveckla säkerhets- och försvarspolitiken. Frågan är om britterna nu kan ställa sig utanför det säkerhets- och försvarspolitiska samarbetet inom EU och om EU å sin sida kan avstå de militära och försvarsindustriella kapaciteter Storbritannien besitter. Vad gäller säkerhets- och försvarspolitiken innebär den aktuella utvecklingen däremot att Storbritannien - paradoxalt nog - kan komma att öka sitt samarbete med $\mathrm{EU}$ och acceptera ett betydligt djupare och mer långtgående samarbete än vad som förmodligen hade varit fallet om man aldrig inlett utträdesprocessen. Sammanfattningsvis kan man nog därför dra slutsatsen att den brittiska 
ambitionen att återta kontrollen kommer att gälla på många områden samtidigt som det säkerhets- och försvarspolitiska samarbetet går längre än tidigare mycket beroende på att just Brexit skapade nya möjligheter för EU att ta avgörande steg mot att utveckla strategiskt aktörskap och eftersträva strategisk autonomi.

\section{En bredare koalition}

Ett initiativ inom europeisk säkerhets- och försvarspolitik är European Integration Initiative, EI2, lanserat av president Macron i september 2017 (President Macron's Initiative for Europé, 2017). EI2 som blev verklighet den 25 juni 2018 är inte tänkt som något alternativ till PESCO utan är snarare ett komplement. Motivet att lägga EI2 utanför EU är att skapa en mer flexibel process som inte är lika bunden av formella institutioner. Ett annat syfte har varit att inkludera Danmark och Storbritannien fullt ut i samarbetet. Från fransk synvinkel är förstås brittisk medverkan viktig eftersom de sedan 2010 har ett bilateralt samarbetsavtal, "The Lancaster House Treaty» som har det uttryckliga syftet:

to develop co-operation between our Armed Forces, the sharing and pooling of materials and equipment including through mutual interdependence, the building of joint facilities, mutual access to each other's defence markets, and industrial and technological co-operation ... and to pursue joint initiatives in the areas of operations equipment and capabilities and unmanned air systems. (Prime Minister's Office, 2010)

Syftet med EI2 är däremot inte, som man skulle kunna tro, att sätta upp en gemensam europeisk militär styrka för att kunna genomföra interventioner utan handlar snarare om att utveckla en gemensam strategisk vision och en gemensam strategisk kultur bland annat genom att dela strategisk information, planering, scenarier, stödja operationer och inte minst hantera kriser m.m. I en nyligen utkommen nederländsk rapport analyseras EI2 just utifrån begreppet strategisk kultur. Författarna finner att EI2:s medlemmar har skiftande förutsättningar och erfarenheter för att agera samlat. Bland de mer ambitiösa identifierar man Frankrike, Storbritannien, Danmark och Nederländerna, och bland de mindre aktiva Finland och Spanien, bland annat beroende på att skilda geopolitiska förutsättningar bidrar till skiftande hotbilder och prioriteringar (Zandee \& Kruijver, 2019). Ser vi EI2 som en del av den övergripande säkerhetspolitiska strukturen i Europa är det tydligt att EI2 på flera sätt förenar franska och brittiska intressen och positioner. Macron signalerar att på det här området krävs ett mer flexibelt och inkluderande samarbete som inte binds upp av EU:s regelverk - helt klart en samsyn med den brittiska positionen. Dessutom delar den franske presidenten och den brittiske premiärministern en kompetens att agera på det säkerhetspolitiska området som går längre än vad som är fallet i flera europeiska länder (Zandee \& Kruijver, 2019). Eftersom EI2 inlett samarbete med PESCO på projektnivå 2018 innebär detta potentiellt en möjlighet för Storbritannien att påverka PESCO bakvägen. 
En vidare och mer långsiktig strategisk respons som ibland ventileras gäller möjligheten att skapa en bredare lös koalition av stater på global nivå som tillsammans kan upprätthålla såväl en liberal världsordning som multilaterala former. En sådan lös koalition skulle kunna axla USA:s ledande roll på flera områden i ett läge där USA åtminstone temporärt väljer att ta ett steg tillbaka. Ingen ledande liberal demokratisk makt kan ensam överta USA:s roll inom överskådlig framtid, bara tillsammans kan det ske. EU och flera europeiska stater skulle finnas med i en sådan koalition. Grundtanken är helt enkelt att USA:s närmast allierade som kollektiv har tillräcklig både ekonomisk och militär kapacitet för att skydda den liberala världsordningen. Det kan gälla makter som Frankrike, Tyskland, Storbritannien, EU, Australien, Japan, Sydkorea och Kanada. Målet skulle vara att försvara en liberal och multilateral ordning i vilken USA kan komma att ingå. På det säkerhets- och försvarspolitiska området skulle till exempel en rejäl satsning inom Europa på kapacitetsutveckling genom PESCO och genom att följa $2 \%$-målet innebära att Europas samlade kapacitet ökar väsentligt (se t.ex. Lindsay \& Daalder, 2018). USA har under efterkrigstiden varit centralt för globala ekonomiska relationer och institutioner. Trumps konkurrensorienterade politik med hot om handelskrig och försök att ersätta multilaterala institutioner med bilaterala avtal till USA:s fördel - en slags 'bilateralisering' - gav USA en annan roll i världsekonomin. Under 2019 kunde emellertid EU efter långa förhandlingar träffa ett handelsavtal med MERCOSUR, något som visar på EU:s förmåga att agera oberoende av USA. De senaste åren har EU även slutit handelsavtal med både Japan och Kanada. Hur långt det är möjligt att agera i sådana här sammanhang och på bred front utan amerikanskt ledarskap är inte en fråga att närmare analysera här. Situationen är en annan med president Biden. Exemplen visar $i$ alla fall att $\mathrm{EU}$ har kapacitet att agera samlat på global nivå som en partner till USA och andra makter. I en värld där liberaldemokratiska stater i ökande grad upplever liknande hot från icke-demokratiska eller antiliberala rörelser och stater, både ekonomiskt och militärt, kan en ökad europeisk försvarsförmåga komplettera handelsavtal och skapa möjliga partnerskap långt bortom Europas gränser. Men de krav som ställs i termer av strategisk autonomi och strategiskt aktörskap handlar då nog först och främst om förmågan att tala med en röst.

Utsikterna att åstadkomma en koalition av den typ som här har skisserats är förstås svåra att bedöma, men om europeiska stater lyckas att utveckla sina försvarspolitiska samarbeten och stärka sin förmåga och sin ställning inom Nato har man tagit avgörande steg på vägen. Resonemang i den här riktningen finns även i EU:s globala strategi:

To remain, and become even more, the go-to power in a world in which multilateralism is questioned, we must continue to invest consistently in our collective capacity to act autonomously and in cooperation with our partners. (European Union, 2019, s. 10)

Den europeiska kapacitetsuppbyggnaden är således inte enbart en väg för EU att stärka sin försvarsförmåga under amerikansk strategisk reträtt utan är även ett sätt 
att försvara en liberal och multilateral världsordning. Detta tydliggörs också av EU:s vilja att engagera så kallade tredjeländer i sina internationella insatser där bland annat Kanada, USA och Chile har deltagit, men även mer närbelägna länder som exempelvis Schweiz, Turkiet och Georgien (Lords European Union Committee, 2018, kap. 4; Koenig, 2019). Det bör dock framhållas att även om en demokratisk administration i Washington skulle eftersträva att återge USA ett globalt ledarskap med liberala förtecken så kan det ändå innebära fortsatt strategisk återhållsamhet (Warren, 2019).

Med Storbritannien utanför EU finns förstås en risk att den internationella liberalismen försvagas till förmån för nationalism. Samtidigt har Storbritannien betonat att man som global makt vill bidra till att "binda samman» de demokratier och på så vis göra världen säkrare (Hunt, 2019). Det finns även en geopolitisk aspekt av detta. Nina Graeger och Kristin M. Haugevik diskuterar två olika geopolitiska positioner som möjligen kan förklara de olika hållningar vi här möter: Å ena sidan europeanism, en position som har Frankrike som främsta företrädare och där det centrala är att balansera USA:s inflytande över Europa genom ett utvecklat europeiskt försvarssamarbete. Å andra sidan atlantisism, företrädd av Storbritannien och som baseras på ett geopolitiskt tänkande där banden mellan USA och Storbritannien är centrala och med vilka följer en skeptisk syn på europeisk integration inom försvarsområdet. De båda positionerna speglar äldre geopolitiskt tänkande om sjömakter och landmakter. USA:s roll under 1900-talet har förskjutit perspektivet mot atlantisismen. Föreställningen om den transatlantiska länken är central för detta perspektiv, men representerar idag även en tredje hållning, euroatlantisism (Graeger \& Haugevik, 2009). Att stärka EU:s roll i relation till Nato behöver inte innebära ett brott med Nato eller USA; det är som framgår ovan en tydlig ambition inom EU att både stärka den egna förmågan och att vidmakthålla den transatlantiska länken. Brexit och framväxten av nya europeiska institutioner innebär kanske inte att Storbritannien helt överger atlantisismen men intresset av att delta i och utveckla dessa institutioner bortom att vara tredje land speglar inte bara Storbritanniens kapacitet utan visar trots allt på insikten att ett samarbete mellan EU och Storbritannien är intressant.

Här kan även den "bilateralisering» som eftersträvades av Trumpadministrationen vara en viktig faktor för att Storbritannien ska närma sig EU. Som diskuteras av Charlotte Wagnsson har Storbritannien tidigare, i valet mellan USA och Europa, valt USA eftersom landet företrätt vissa liberaldemokratiska normer oavsett om detta inneburit exkludering av vissa stater från samarbetsforum eller om det inneburit brott mot uppförandekoder inom ramen för FN-samarbete (Wagnsson, 2008). Britterna förefaller dessutom ha varit relativt nöjda med den unipolära världsordning där USA tagit störst ansvar. En förändrad amerikansk utrikespolitik där ansvar för internationell fred och säkerhet inte längre ska tas för given och med en »bilateralisering» av utrikespolitiken som tar mindre hänsyn till liberaldemokratiska normer innebar förstås en utmaning för Storbritannien (Shipman, 2020). Efter Brexit blir Storbritannien en mindre viktig partner för USA (Michaels, 2019). Av dessa skäl är 
det inte uppenbart vilka konsekvenser Brexit får i relation till transatlantisk säkerhet, trots det omtalade "Special Relationship" (Foerster \& Raymond, 2017). Lösningen för Storbritannien är kanske trots allt euroatlantisismen där det finns beröringspunkter med EU:s hållning såväl som med EI2.

Bildandet av EI2 öppnade tidigare stängda möjligheter för säkerhets- och försvarspolitiskt samarbete mellan stater som är medlemmar respektive står utanför EU eller Nato, vilket skulle kunna bidra till en stärkt europeisk nod i en bredare koalition. Av det skälet öppnas också möjligheter för de nordiska länderna till ett fördjupat nordiskt samarbete när det gäller försvars- och säkerhetsfrågor. Den transatlantiska länken är central för de nordiska ländernas säkerhets- och försvarspolitik. Detta gäller naturligtvis Natoländerna Norge och Danmark, men även Sverige och Finland som de sista åren har utvecklat samarbetet med såväl Nato som Storbritannien och USA. Nato har emellertid alltid varit en vattendelare när det gäller nordiskt samarbete inom säkerhets- och försvarsområdet. För Sveriges och Finlands del har de senaste åren inneburit stora förändringar i säkerhets- och försvarspolitiken, både vad gäller samarbeten mellan länderna som samarbete med USA och Storbritannien, bilateralt och multilateralt, politiskt såväl som operativt och inom försvarsindustrin. Sverige har exempelvis ett omfattande försvarsindustriellt samarbete med Storbritannien vilket skulle underlättas om Storbritannien fick en ställning inom EDF.

Trots "EU-forsvarsforbeholdet» har utvecklingen av europeiskt försvarssamarbete inneburit om inte en positionsförändring, så i varje fall en viss nyfiken öppenhet i Danmark och frågan har lyfts i debatten om hur Danmark bör förhålla sig till ett utvecklat europeiskt försvarssamarbete (Vormsby, 2017). Blir EU:s försvarssamarbete viktigare riskerar Danmark att förlora inflytande (Ringsmose, 2017). På så sätt blir EI2 en väg för Danmark att skaffa sig mer inflytande (Cold-Ravnklide et al., 2018). En annan möjlighet är att bidra till EDF (Regeringen i Danmark, 2018). Norge har uttryckt önskan om att bli inkluderat i EU:s Brexit-förhandlingar eftersom Storbritanniens status efter Brexit kan komma att påverka "Norges tilværelse som utenforland" (Haugevik, 2017). I den norska debatten diskuteras 2017 om Norge kan emotse ett nytt säkerhetssamarbete med EU av liknande typ som Storbritannien (Vermes, 2017). Ulf Sverdrup menar att Mays utspel ger Norge en chans att ingå i ett eventuellt nytt säkerhetsfördrag. Det skulle kunna vara att föredra eftersom Norges säkerhetssamarbete med EU består av många olika avtal och informella överenskommelser. Genom att ingå i ett mer strukturerat samarbete skulle Norge knyta sig närmare både EU och Storbritannien (Sverdrup, 2017). På så sätt skulle Norge, beroende på EU:s och Storbritanniens framtida relation, eventuellt kunna "följa med» in i ett närmare samarbete om Storbritannien skulle kunna få en status som »tredjeland + ".

Det kan alltså konstateras att det ökade samarbetet inom ramen för EU och inom EI2 på sikt även kan få konsekvenser för de nordiska ländernas möjligheter att fördjupa sitt samarbete. Skiljelinjen mellan Natoländer och icke-Natoländer har varit tydlig i det nordiska samarbetet. Samtidigt innebär EI2 en ny arena för nordiskt 
samarbete. Arbetet både i PESCO och i EI2 skulle på sikt möjligen kunna bidra till att luckra upp den hårda uppdelningen mellan å ena sidan Natos fokus på territorialförsvar och å andra sidan EU:s inriktning på internationella insatser. Danmark precis som Storbritannien kan utan problem kombinera Nato och EI2 och Danmark har hittills varit en av de mer aktiva medlemmarna av EI2 (Zandee \& Kruijver, 2019).

\section{Slutsatser}

Den här artikeln visar hur amerikansk strategisk återhållsamhet sedan 2017 har mötts av europeisk strategisk respons i form av fortsatt stöd till internationell liberalism, europeisk förmågeuppbyggnad och en europeisk ambition att bli en mer självständig och strategiskt autonom aktör i den internationella politiken. Det handlar ur ett europeiskt perspektiv inte bara om nationella säkerhetsintressen utan även om EU:s framtid och om hur den världsordning som européer vant sig vid att uppskatta ska kunna upprätthållas och utvecklas. Att enas om och försvara ett liberalt strategiskt narrativ både inom Europa och gentemot omvärlden är ett förhållandevis enkelt och kanske självklart val. Men ambitionerna att stärka den europeiska förmågan innebär även motsättningar när det gäller frågan om graden av strategisk autonomi och relationen till främst Nato. På längre sikt söker Europa möjligheter att tillsammans med andra främja multilaterala och liberala institutioner. En sådan ambition tydliggör olika och ibland motsatta geopolitiska perspektiv.

Den mest påtagliga responsen är stärkandet av europeisk förmåga och uppbyggnaden av nya institutioner och samarbeten. Förmågeuppbyggnaden var ett sätt att väga upp och stabilisera en möjligen sviktande transatlantisk länk. Med president Biden kan vi förvänta en mer samarbetsvillig och multilateralt inriktad politik, men förmodligen även fortsatt strategisk återhållsamhet och krav på Natos medlemsstater att leva upp till det $2 \%$-målet. Brexit har paradoxalt nog fått Storbritannien att vilja medverka i arbetet med att utveckla europeisk försvarsförmåga. Detta må vara ett sätt att möta amerikansk strategisk återhållsamhet men är inget alternativ till transatlantiskt samarbete. Däremot gör det EU och Europa som helhet mindre sårbart och bättre rustat att svara upp mot amerikanska krav. De båda alternativen för strategisk respons har emellertid en väsentlig aspekt gemensam: i båda fallen är USA en viktig och avgörande partner. Övervintringsalternativet förutsätter att USA på lite längre sikt är berett att främja och garantera en liberal världsordning. Stärkandet av europeisk försvarsförmåga och samlade institutioner förutsätter under överskådlig tid den transatlantiska länken och Nato. Givet fortsatt strategisk återhållsamhet från USA:s sida kan det leda till en ökad betoning av strategisk autonomi för Europa inom ramen för EU, vilket kan skärpa konflikter mellan olika europeiska stater. De olika initiativ som har tagits har också medfört nya möjligheter, exempelvis nya förutsättningar för nordiskt säkerhets- och försvarssamarbete som en följd av EI2. Den strategiska respons som vi har kunnat analysera sedan 2017 visar att Europa liksom Norden definitivt har slagit in på en ny säkerhets- och försvarspolitisk väg. 


\section{Acknowledgements}

Artikeln är skriven inom ramen för projektet Transatlantisk säkerhets- och försvarspolitik. Vi vill tacka för värdefulla bidrag och synpunkter från Kjell Engelbrekt, Maria Hellman, Braxton Palmer och Julia Aurell samt två anonyma granskare.

\section{Författarpresentation}

Ronnie Hjorth är professor i statsvetenskap vid Försvarshögskolan i Stockholm. Malena Britz är docent i statsvetenskap och prorektor för Försvarshögskolan i Stockholm.

\section{Referenser}

Beckley, M. (2018). Unrivaled: Why America will remain the world's sole super power. Cornell Univeristy Press.

Black, J., Hall, A., Cox, K., Kepe, M. \& Silfversten, E. (2017). Defence and security after Brexit: Understanding the possible implications of the UK's decision to leave the EU. RAND Europe.

Britz, M. (2016). European participation in international operations:The role of strategic culture. Palgrave Macmillan.

Britz, M. \& Eriksson, A. (2005). European foreign and security policy: A fourth system of European foreign policy? Politique Européenne, 3(17), s. 35-62.

Britz, M. \& Eriksson, A. (2008). Analyzing EU's shared strategy. I K. Engelbrekt \& J. Hallenberg (Red.), The European Union and strategy: An emerging actor (s. 56-70). Routledge.

Cold-Ravnklide, M., Nissen, C. \& Moe Fejerskov, A. (2018). The Franco-German axis prompts new Danish strategy: Danish security and defence cooperation in a changing world. Dansk institute for international studies. https://pure.diis.dk/ws/files/2456537/PB_Franco_German_Axis_WEB.pdf

Cottey, A. (2018). The EU's common security and defence policy: Institutions without strategy. I S. Economides \& J. Sperling (Red.), EU security strategies extending the EU system of security governance (s. 125-142). Routledge.

Council of the European Union. (2018, 22 november). Political declaration setting out the framework for the future relationship between the European Union and the United Kingdom. http://data.consilium.europa. eu/doc/document/XT-21095-2018-INIT/en/pdf?fbclid=IwAR1RupRVKch-wgpait_-TdBJ2noDFwodOivYFbBALpXhzTNhnNkDeWlKhQ

Department for Exiting the European Union. (2017, 12 september). Foreign policy, defence and development - a future partnership paper. HM Government. https://assets.publishing.service.gov.uk/government/uploads/ system/uploads/attachment_data/file/643924/Foreign_policy_defence_and_development_paper.pdf

Drezner, D. W. (2019). This time is different: Why U.S. foreign policy will never recover. Foreign Affairs, 98(3), 10-17.

Economides, S. \& Sperling, J. (2018). EU security strategies extending the EU system of security governance. Routledge.

Engelbrekt, K. (2008). The making of a security and defence strategy. I K. Engelbrekt \& J. Hallenberg (Red.), European Union and strategy. An emerging actor. Routledge.

European Union. (2019). The European Union's global strategy: Three years on, looking forward. Brussels.

Foerster, S. \& Raymond, R. (2017). The US-UK “special relationship" at a critical crossroads. Atlantic Council.

Gholz, E., Press, D. G. \& Sapolsky, H. M. (1997). Come home America: The strategy of restraint in the face of temptation. International Security, 21(4), 5-48.

Graeger, N. \& Haugevik, K. M. (2009). The revival of Atlanticism in NATO? Changing security identities in Britain, Norway and Denmark. Norwegian Institute of International Affairs.

Haugevik, K. M. (2017). Hva betyr brexit for utenforlandet Norge? Internasjonal Politikk, 75(2), $152-166$.

H. M. Government. (2018, 12 juli). The future relationship between the United Kindgom and the European Union. https://assets.publishing.service.gov.uk/government/uploads/system/uploads/attachment_data/ file/786626/The_Future_Relationship_between_the_United_Kingdom_and_the_European_Union_ 120319.pdf 


\section{Ronnie Hjorth og Malena Britz}

Hunt, J. (2019, 14 maj). Lord Mayor's banquet 2019: Foreign secretary's speech. HM Government. https://www. gov.uk/government/speeches/lord-mayors-banquet-2019-foreign-secretarys-speech

Ikenberry, J. (2001). After victory: Institutions, strategic restraint, and the rebuilding of order after major wars. Princeton Univeristy Press.

Jervis, R., Gavin, F., Rovner J. \& Labrosse, D. N. (2018). Chaos in the liberal order: The Trump presidency and international politics in the twenty-first century. Columbia University Press.

Kissinger, H. (1994). Diplomacy. Simon \& Schuster.

Koenig, N. (2019). Revamping CSDP partnerships in the shadow of Brexit. EU Global Strategy Watch 9.

Layne, C. (1997). From preponderance to offshore balancing: America's future grand strategy. International Security, 22(1), 86-124.

Lindsay, J. M. \& Daalder, I. H. (2018). The committee to save the world order: America's allies must step up as America steps down. Foreign Affairs, 97(6), 72-83.

Lords European Union Committee. (2018). Chapter 4: Third country participation in CSDP mission I Brexit: Common security and defense policy missions. https://publications.parliament.uk/pa/ld201719/ldselect/ ldeucom/132/13207.htm\#_idTextAnchor055

Mearsheimer, J. J. \& Walt, S. M. (2016). The case for offshore balancing: A superior US grand strategy. Foreign Affairs, 95(4), 70-83.

Michaels, J. H. (2019). "You don't hear the word Britain anymore": Anglo-American security relations in the era of Brexit and Trump. I R. Johnson, \& J. Haaland-Marlary (Red.), The United Kingdom's defence after Brexit. Palgrave Macmillan.

Monen, J. (2005). The roots of the Bush doctrine: Power, nationalism, and democracy promotion in U.S. strategy. International Security, 29(4), 112-156.

Munich Security Conference. (2017). Munich security report: Post-truth, post-West, post-order?

Munich Security Conference. (2019). Munich security report: The great puzzle: Who will pick up the pieces? https://espas.secure.europarl.europa.eu/orbis/sites/default/files/generated/document/en/MunichSecurity Report2019.pdf

NSS. (2017), National Security Strategy of the United States of America.

Permanent Structured Cooperation-PESCO Factsheet. (2019). European Union External Action. https://eeas. europa.eu/sites/eeas/files/pesco_factsheet_november_2019.pdf

President Macron's Initiative for Europe. (2017, 26 september). France Diplomatie: Ministry for Europe and Foreign Affairs. https://www.diplomatie.gouv.fr/en/french-foreign-policy/european-union/news/article/ president-macron-s-initiative-for-europe-a-sovereign-united-democratic-europe

Prime Minister's Office, 10 Downing Street. (2010, 2 november). HM Government. UK-France Summit 2010 Declaration on Defence and Security Co-operation. https:/www.gov.uk/government/news/uk-francesummit-2010-declaration-on-defence-and-security-co-operation

Rapp-Hooper, M. \& Friedman Lissner, R. (2019). The open world: What America can achieve after Trump. Foreign Affairs, 98(3), 18-25.

Regeringen i Danmark. (2018) Udenrigs-og Sikkerhedspolitisk Strategi2019-2020. Danmarks Udenrigsministeriet. https:/um.dk/da/udenrigspolitik/aktuelle-emner/udenrigs-og-sikkerhedspolitisk-strategi-2019-20/

Regulation (EU) 2018/1092 of the European Parliament and of the Council. (2018, 18 juli). EUR-Lex. https:// eur-lex.europa.eu/legal-content/EN/TXT/?uri=CELEX\%3A32018R1092

Ringsmose, J. (2017, 30 augusti). Militcerforsker: Ny sikkerhedspolitik efter Ukraine, Brexit og Trump. https://www. altinget.dk/eu/artikel/forsvarsakademiet-sikkerhedspolitik-efter-ukraine-brexit-og-trump

Rosen, B. R. (2014). Strategic restraint: A new foundation for US grand strategy. Cornell University Press.

Schmidt, P. \& Zyla, B. (2013). European Security Policy and Strategic Culture. Lindon: Routledge.

Shipman, T. (2020, 12 januari). Ben Wallace interview: We can't rely on US. The Sunday Times. https://www. thetimes.co.uk/article/ben-wallace-interview-we-cant-rely-on-us-pmwcgv398

Smale, A. \& Erlanger, S. (2017, 28 maj). Merkel, after discordant G-7 meeting, is looking past Trump. The New York Times. https://www.nytimes.com/2017/05/28/world/europe/angela-merkel-trump-alliances-g7leaders.html?auth=login-email\&login=email

Smith, M. E. (2018). Transatlantic security relations since the European security strategy: What role for the EU in its pursuit of strategic autonomy? Fournal of European Integration, 40(5), 605-620.

Sverdrup, U. (2017, 12 november). Brexit og europeisk sikkerhet: Kan brexit gjøre at Norge og Storbritannia blir tettere integrert med EU? Det kan skje i sikkerhetspolitikken. Dagens Naeringsliv. https://www.dn.no/ globalt/sikkerhetspolitikk/politikk/brexit/brexit-og-europeisk-sikkerhet/2-1-207505 
Vermes, T. (2017, 30 oktober). Tror Brexit kan gi Norge en lenge ønsket forsvarsavtale med EU. ABC Nyheter. https://www.abcnyheter.no/nyheter/politikk/2017/10/30/195343962/tror-brexit-kan-gi-norge-en-lengeonsket-forsvarsavtale-med-eu

Vormsby, S. (2017, 6 april). Fransk forsvar får mere magt i EU og NATO efter Brexit. Taenketanken Europa. http://thinkeuropa.dk/politik/fransk-forsvar-faar-mere-magt-i-eu-og-nato-efter-brexit

Wagnsson, C. (2008). Security in a greater Europe: The possibility of a pan-European approach. Manchester University Press.

Walt, S. M. (2019). The end of hubris: And the new age of American restraint. Foreign Affairs, 98(3), 26-35.

Warren, E. (2019). A foreign policy for all: Strengthening democracy - at home and abroad. Foreign Affairs, 98(1), 50-61.

Wertheim, S. (2018). Trump against exceptionalism: The sources of Trumpian conduct. I E. Jervis (Red.), Chaos in the liberal order: The Trump presidency and international politics in the twenty-first century (s. 125135). Columbia University Press.

Williamson, G. (2019, 11 februari). Speech: Defence in global Britain. HM Government: https://www.gov.uk/ government/speeches/defence-in-global-britain

Zandee, D. \& Kruijver, K. (2019). The European intervention initative: Developing a shared strategic culture for European defence. Clingendael, Netherlands Institute of International Relations.

\section{Abstract in English \\ American Strategic Restraint and European Strategic Response: Three Forms of Strategic Response Post-Brexit}

This paper describes and analyses three types of European strategic response since the year 2017 by European governments and the EU in response to US strategic restraint and conditioned by Brexit. The three types of response we label "liberal wintering", "a stronger Europe" and "a broader coalition". The paper links strategic response to strategic agency and strategic autonomy leading on to two main conclusions: First, that Brexit has done more to promote than to restrain the development of European common security and defence, both within the EU and when involving nations outside of the EU, such as the UK. Second, that the new broader European security and defence structures open the door to new forms of cooperation, for example between the Nordic countries.

Keywords: transatlantic security • European security • Nordic security • Brexit • international relations 